\title{
PENGARUH INVENTORY TURNOVER (ITO), DEBT TO EQUITY RATIO (DER), RETURN ON ASSET (ROA), EARNING PERSHARE (EPS), DAN PRICE EARNING RATIO (PER) TERHADAP RETURN SAHAM PADA PERUSAHAAN FOOD AND BEVERAGE YANG TERDAFTAR DI BURSA EFEK INDONESIA
}

\author{
Ria Veronica Sinaga \\ Universitas Katolik Santo Thomas Medan Jl. Setia Budi No. 479F, 20132, Indonesia \\ e-mail: riaveronicasinaga@yahoo.com
}

\begin{abstract}
This study aims to determine the effect of Inventory Turnover (ITO), Debt to Equity Ratio (DER), Return On Assets (ROA), Earning Per Share (EPS), Price Earning Ratio (PER) to Stock Returns on registered Food and Beverage Companies on the Indonesia Stock Exchange. The benefit of research is to provide information material to investors in making investment decisions. The number of companies to be sampled is 10 Food and Beverage Companies, namely: PT. Akasha Wira International Tbk (ADES), PT. Tiga Pilar Sejahtera Food Tbk (AISA), PT. Cahaya Kalbar Tbk (CEKA), PT. Multi Bintang Indonesia Tbk (MLBI), PT. Multi Bintang Indonesia Tbk (MLBI), PT. Sekar Laut Tbk (SKLT), PT. Ultrajaya Milk Industry and Trading Company Tbk (ULTJ), PT. Prashida Aneka Niaga Tbk (PSDN), PT. Indofood Sukses Makmur Tbk (INDF), PT. Delta Djakarta Tbk (DLTA), and PT. Mayora Indah Tbk (MYOR). In this study, secondary data is used, namely the Financial Report of Food and Beverage Companies listed on the Indonesia Stock Exchange for the period 2012-2016 which can be accessed via the internet. The data analysis method used is multiple regression analysis. Based on the results of the study, the regression equation was obtained as follows: Return $=-42,736+0,731$ ITO $+13,582$ DER + 3,306 ROA - 0,003 EPS + 3,203 PER + e showed that the ITO variable had a positive and not significant effect, the DER variable had a positive and insignificant effect. ROA variable has a positive and significant effect, EPS variable has a negative and not significant effect, and PER variable has a positive and significant effect on stock returns. ITO, DER, ROA, EPS and PER simultaneously influence the stock return of hospitality service companies. adjusted $R 2$ value of 0.164 . This means that 16.4 percent of variations in stock return variables can be explained by variations in ITO, DER, ROA, EPS and PER variables while the remaining 83.6 percent is explained by other variables outside the model.
\end{abstract}

Keywords: Inventory Turnover, Debt to Equity Ratio, Return On Asset, Earning Per Share, Price Earning Ratio, and Stock Return

\section{PENDAHULUAN}

Di era ekonomi modern seperti sekarang ini, perusahaan sangat membutuhkan tambahan modal untuk mendorong kinerja operasional perusahaan. Salah satu cara bagi perusahaan untuk mendapatkan tambahan modal adalah dengan menawarkan kepemilikan perusahaan tersebut kepada masyarakat/publik (go public). Pasar modal merupakan tempat bagi perusahaan untuk menghimpun dana yang berfungsi untuk membiayai secara langsung kegiatan perusahaan dengan cara melakukan penawaran saham kepada masyarakat di bursa efek yang sering di sebut go public.

Salah satu fungsi pasar modal adalah sebagai sarana untuk memperoleh dana yang bersumber dari masyarakat ke berbagai sektor yang melaksanakan investasi. Syarat utama yang diinginkan oleh para investor untuk bersedia menyalurkan dananya melalui pasar modal adalah perasaan aman akan investasi dan tingkat return yang akan diperoleh. Pasar modal memperdagangkan beberapa jenis sekuritas yang mempunyai tingkat risiko berbedabeda. Saham merupakan salah satu sekuritas yang mempunyai tingkat risiko cukup tinggi. Risiko tinggi tercermin dari ketidakpastian return yang akan diterima oleh investor masa depan. Situasi ketidakpastian ini mendorong investor yang rasional untuk selalu 
mempertimbangkan risiko dan expected return setiap sekuritas yang secara teoritis berbanding lurus. Semakin besar expected return maka tingkat risiko yang melekat juga semakin besar. Risiko dalam investasi saham dapat dikelompokkan atau digolongkan menjadi dua risiko yaitu : risiko sistematis dan risiko tidak sistematis (unsystematic risk). Risiko sistematis adalah bagian dari risiko sekuritas yang tidak dapat dihilangkan dengan diversifikasi atau membentuk portofolio,istilah lain dari risiko ini adalah risiko pasar atau risiko umum. Sedangkan risiko tidak sistematis (unsystematic risk) adalah risiko yang berhubungan dengan keadaan perusahaan sebagai suatu lingkup investasi yang mempunyai karakteristik sendiri, berbeda dengan perusahaan lainya.

Informasi yang diperlukan oleh investor di pasar modal meliputi informasi yang bersifat fundamental dan teknikal. Informasi yang bersifat teknikal seperti: keadaan perekonomian, sosial dan politik suatu negara. Selain memperhatikan informasi yang teknikal ,investor juga mulai memperhatikan informasi yang bersifat fundamental yang diperoleh dari intern perusahaan khususnya kondisi keuangan perusahaan dalam melakukan transaksi saham di Bursa Efek Indonesia (Rosyadi, 2002).

Laporan keuangan merupakan informasi yang lazim digunakan karena laporan keuangan perusahaan diharapkan dapat memberikan informasi bagi calon investor dan calon kreditur guna mengambil keputusan yang terkait dengan investasi dana mereka. Informasi akuntansi dalam bentuk laporan keuangan akan memberikan banyak manfaat bagi para pengguna apabila laporan tersebut dianalisis lebih lanjut sebelum dimanfaatkan sebagai alat bantu pembuat keputusan bisnis pada saat aktivitas jual beli saham di bursa efek. Agar dapat dijadikan sebagai salah satu alat pengambil keputusan yang andal dan bermanfaat. Dari laporan keuangan perusahaan dapat diperoleh informasi tentang kinerja, aliran kas perusahaan, dan informasi lain yang berkaitan dengan laporan keuangan. Informasi tersebut setidaknya harus memungkinkan investor untuk melakukan proses penilaian (valuation) saham yang mencerminkan hubungan antara risiko dan hasil pengembalian yang sesuai dengan preferensi masing-masing investor. Suatu laporan keuangan dikatakan memiliki kandungan informasi bila publikasi dari laporan keuangan tersebut menyebabkan bergeraknya reaksi pasar.

Reaksi pasar mengacu pada investor dan pelaku pasar lainnya untuk melakukan transaksi (baik membeli atau menjual) saham sebagai tanggapan atas keputusan penting emiten yang disampaikan ke pasar. Reaksi pasar ini di tunjukan dengan adanya perubahan dari harga saham yang lazimnya diukur dengan menggunakan return saham sebagai nilai perubahannya.

Salah satu alat untuk menganalisis harga saham adalah dengan analisis ratio. Analisis ratio merupakan alat yang membantu kita untuk menganalisis laporan keuangan perusahaan sehingga kita dapat mengetahui kekuatan dan kelemahan suatu perusahaan. Analisis ratio juga menyediakan indikator yang dapat mengukur tingkat profitabilitas, likuiditas, pendapatan / pemanfaatan asset dan kewajiban suatu perusahaan (Dharmastuti,2004:17).

Manao dan Nur (2001) melakukan penelitian mengenai pengaruh rasio keuangan terhadap return saham pada perusahaan manufaktur di Indonesia yang terdaftar di Bursa Efek Jakarta dengan mempertimbangkan ukuran perusahaan serta pengaruh krisis ekonomi yang terjadi di Indonesia. Pengukuran rasio keuangan dalam penelitian ini mengunakan rasio liquidity yang diwakili oleh quick ratio, rasio activity dinyatakan dengan total assets turnover, rasio leverage diukur dengan current liabilities to total asset dan long term debt to total assets, rasio profitability dijelaskan dengan gross profit margin dan return on equity, rasio yang terakhir adalah capital market menggunakan price to book value dan earning per share. Hipotesis yang diajukan adalah pengaruh return saham dengan informasi rasio keuangan. Perusahaan sebagai sampel dibagi menjadi tiga jenis ukuran yang itu large firm, medium firm dan small firm. Penentuan ukuran perusahaan ini didasarkan pada total aset perusahaan. Semua perusahaan setiap tahun sampel akan dirangking berdasarkan jumlah total asetnya. Kategori

Pengaruh Inventory Turnover (ITO), Debt To Equity Ratio (DER), Return On Asset (ROA), Earning 29 Pershare (EPS), dan Price Earning Ratio (PER) Terhadap Return Saham pada Perusahaan 
perusahaan besar adalah sepertiga bagian atas, sepertiga bagian bawahnya dinyatakan sebagai perusahaan menengah dan kecil. Hasil penelitian ini menunjukkan earnings per share secara konsisten berasosiasi secara positif dan signifikan terhadap return saham untuk semua ukuran perusahaan. Pada hipotesis menyatakan bahwa kekuatan asosiasi antara return saham dengan rasio keuangan berbeda secara signifikan untuk berbagai ukuran perusahaan tidak sepenuhnya ditolak. Kekuatan asosiasi di antara jenis-jenis perusahaan tersebut berbeda secara signifikan satu dengan yang lain. Semakin besar ukuran perusahaan,maka semakin besar pulalah kekuatan asosiasi antara return saham dengan informasi laporan keuangannya. Pada perusahaan menengah hanya variabel ROE, PBV dan EPS yang signifikan terhadap return saham.

Anugerah, Habbe dan Kadir (2001) melakukan pengujian terhadap korelasi antara price earning ratio dengan return saham pada perusahaan go public di Bursa Efek Jakarta. Sampel yang digunakan dalam penelitian ini adalah perusahaan yang go publik di Bursa Efek Jakarta (BEJ) tahun 1991 - 1995. Price earning ratio merupakan salah satu analisis rasio yang digunakan untuk mengambil keputusan investasi. Dari segi investor, PER yang terlalu tinggi barangkali tidak menarik sebab harga saham mungkin tidak akan naik lagi yang berati kemungkinan memperoleh capital gain akan kecil (Hanafi dan Halim:2003, 85). Hasil dari pengujian menunjukan adanya hubungan negatif antara return saham dan PER terbukti. PER dapat dijadikan sebagai bahan pertimbangan investor untuk melihat besar tidaknya return yakni setiap kenaikan PER mengindikasikan terjadinya penurunan return saham dan penurunan PER mengindikasikan kenaikan return saham. Sehingga investor dapat membeli saham berkategorikan undervalued dan menjual saham overvalued untuk mendapatkan gain yang cukup besar.

Ulupui (2006) melakukan penelitian mengenai pengaruh informasi keuangan dalam bentuk rasio likuiditas, leverage, aktivitas dan profitabilitas terhadap return saham periode satu tahun ke depan. Penelitian ini menggunakan rasio aktivitas diukur dengan total asset turn over (TATO), rasio likuiditas menggunakan current ratio (CR), rasio debt atau leverage dijelaskan dengan debt to equity ratio (DER), sedangkan rasio profitabilitas menggunakan return on asset (ROA). Penelitian ini membuktikan bahwa variabel current ratio memiliki pengaruh yang positif dan signifikan terhadap return saham satu periode ke depan. Hal ini mengindikasikan bahwa pemodal akan memperoleh return yang lebih tinggi jika kemampuan perusahaan memenuhi kewajiban jangka pendeknya semakin tinggi. Variabel return on asset berpengaruh positif dan signifikan terhadap return saham satu tahun periode ke depan, sedangkan variabel debt to equity rasio menunjukkan hasil yang positif tetapi tidak signifikan. Hal ini mengindikasikan rasio utang tidak menyebabkan perubahan return saham satu tahun ke depan. Variabel yang terakhir adalah total asset turn over menunjukan hasil yang negatif dan tidak signifikan.

Artatik (2007) mengadakan penelitian mengenai pengaruh earning pershare dan price earning ratio terhadap return saham pada perusahaan manufaktur yang terdaftar di Bursa Efek Jakarta . Hasil dari penelitian ini menyatakan bahwa EPS berkoefisien positif. Hal ini menandakan semakin tinggi EPS semakin tinggi return saham yang akan diterima oleh investor. Sedangkan variabel PER menunjukkan koefisien negatif, yang artinya PER tidak berpengaruh terhadap return saham. Hal ini berarti semakin tinggi PER maka semakin rendah return saham yang akan diterima dan semakin rendah PER maka return yang akan diterima semakin tinggi. Hal ini senada dengan penelitian Margareth (2008) yang menyatakan bahwa PER tidak berpengaruh terhadap return saham yang akan diterima oleh investor.

Winarto (2007) melakukan penelitian mengenai pengaruh kinerja keuangan terhadap return saham Sampel yang digunakan adalah perusahaan manufaktur yang terdaftar di Bursa Efek Jakarta periode dari tahun 2005. Variabel yang diteliti adalah Debt to Equity Ratio (DER), Earning pershare (EPS), Price Earning Ratio (PER) dan Price to Book Value (PBV) terhadap return 
saham. Hasil penelitian ini menunjukkan bahwa DER, EPS, PBV berpengaruh terhadap return riasaham. Hanya PER yang tidak berpengaruh terhadap return saham.

\section{TINJAUAN PUSTAKA}

\section{A. Teori Investasi}

Investasi merupakan suatu penundaan konsumsi sekarang yang dimasukkan ke dalam proses produksi yang efisien selama periode waktu yang terntentu yang hasilnya untuk konsumsi di masa mendatang (Jogiyanto, 2003). Investasi sering diartikan sebagai suatu penanaman modal untuk satu atau lebih lebih aktiva yang dimiliki dan biasanya berjangka waktu lama dengan harapan mendapatkan keuntungan dimasa-masa yang akan datang. Keputusan penanaman modal tersebut dapat dilakukan oleh individu atau suatu entitas yang mempunyai kelebihan dana. Investasi merupakan komitmen atas sejumlah dana atau sumber daya lainnya yang dilakukan saat ini, dengan tujuan memperoleh keuntungan di masa yang akan datang.

Pasar modal mempunyai peranan penting dalam kegiatan ekonomi sebab pasar modal dapat menjadi sumber dana alternatif bagi perusahaan-perusahaan. Dalam melaksanakan fungsi ekonominya, pasar modal menyediakan fasilitas untuk memindahkan dana dari pihak yang mempunyai kelebihan dana (investor) kepada pihak yang memerlukan dana (emiten). Dengan menginvestasikan kelebihan dana yang mereka miliki, penyandang dana berharap akan memperoleh imbalan dari penyerahan dana tersebut. Bagi peminjam dana, tersedianya dana tersebut pada pasar modal memungkinkan mereka untuk melakukan kegiatan usaha tanpa harus menunggu dana yang mereka peroleh dari hasil operasi perusahaannya.

Salah satu keunggulan utama yang dimiliki pasar modal dibanding dengan bank yaitu untuk mendapatkan dana sebuah perusahaan tidak perlu menyediakan jaminan atau agunan dan tidak perlu menyediakan dana setiap bulan untuk membayar bunga, tetapi membayar dividen kepada investor. Walaupun dalam suatu tahun tertentu merugi, maka perusahaan dapat untuk tidak melakukan pembayaran dividen dan jika sudah memperoleh laba perusahaan baru akan membayarkan dividennya sesuai dengan yang tercantum dalam prospektusnya. Itulah keunggulan yang dinikmati emiten, sedangkan bagi investor yang menginvestasikan dananya di pasar modal juga dapat memperoleh keuntungan yang tidak diberikan oleh bank, yaitu berupa pembayaran dividen yang bahkan mungkin mampu melampui jumlah bunga yang diberikan bank atas investasi yang sama, sekalipun keuntungan ini juga sering disertai oleh resiko yang tidak kecil.

Investasi selalu mengandung unsur risiko, karena perolehan yang diharapkan baru akan diterima pada masa yang kan datang, risiko itu juga timbul karena return yang diterima mungkin lebih besar atau lebih kecil dari dana yang diinvestasikan. Return adalah laba atas suatu investasi yang biasanya dinyatakan sebagai tarif presentase tahunan. Return saham merupakan tingkat keuntungan yang akan diperoleh oleh investor yang menanamkan dananya di pasar modal. Return saham ini dapat dijadikan sebagai indikator dari kegiatan perdagangan di pasar modal.

Return menggambarkan hasil yang diperoleh investor dari aktivitas investasi yang telah dilakukan selama periode waktu tertentu, yang terdiri dari Capital Gain (loss) dan Devidend Yield (Jogiyanto, 2003). Capital gain (loss) merupakan selisih untung (rugi) dari harga investasi sekarang relatif dengan harga periode yang lalu. Devident Yield merupakan persentase penerimaan kas periodik terhadap harga investasi periode tertentu dari suatu investasi.

Dalam penelitian ini return saham yang diperhitungkan adalah return saham yang berasal dari capital gain tanpa memperhitungkan adanya dividend yield. Karena pada dasarnya dividen yang dibagikan nilainya lebih kecil dibandingkan capital gain sehingga tidak terlalu berpengaruh jika tidak ikut diperhitungkan. 
Ulupui (2006) mengatakan bahwa laporan keuangan dapat digunakan untuk meprediksi kesulitan keuangan yang dialami perusahaan, hasil kegiatan operasional, kinerja keuangan perusahaan di masa yang lalu dan yang akan datang, juga sebagai pedoman bagi investor mengenai kinerja perusahaan di masa lalu dan masa mendatang untuk membuat keputusan bisnis. Salah satu alternatif apakah informasi laporan keuangan yang dihasilkan bermanfaat memprediksi harga atau return saham dipasar modal, termasuk kondisi keuangan perusahaan di masa depan adalah rasio keuangan. Rasio-rasio yang digunakan dalam penelitian ini meliputi Inventory Turnover, Debt to Equity Ratio, Return On Asset, Earning Per share, dan Price Earning Ratio.

\section{B. Pengaruh Inventory Turnover terhadap Return Saham}

Inventory Turnover merupakan rasio yang digunakan untuk mengukur kecepatan perputaran persediaan menjadi kas. Semakin cepat inventory terjual, semakin cepat investasi perusahaan berubah dan persediaan menjadi kas. Perusahaan yang perputaran persediaannya makin tinggi berarti makin efisien sehingga tingkat perputaran modal menjadi semakin cepat, perputaran modal yang cepat memberikan harapan untuk memperoleh keuntungan perusahaan semakin tinggi. Perusahaan yang mampu memperoleh keuntungan yang tinngi menunjukkan kinerja perusahaan yang baik dan pada akhirnya dapat memberikan harapan return sahamnya yang semakin baik.

Widodo (2007) dalam penelitiannya membuktikan bahwa Inventory Turnover berpengaruh positif terhadap return saham, dimana semakin tinggi Inventory Turnover menunjukkan kinerja perusahaan yang semakin baik yang berakibat pada peningkatan return saham.

\section{Pengaruh Debt to Equity Ratio terhadap Return Saham}

Debt to Equity Ratio adalah ratio yang memberikan gambaran mengenai struktur modal yang dimiliki perusahaan atau keseimbangan proporsi antara aktiva yang didanai oleh kreditor dan yang didanai oleh pemilik perusahaan, sehingga dapat dilihat tingkat resiko tak tertagihnya suatu utang (Prastowo dan Juliaty,2002:84).

Winarto (2007) melakukan penelitian mengenai Debt to Equity Ratio terhadap return saham. Debt to equity ratio menggambarkan perbandingan antara total utang dengan total ekuitas perusahaan yang digunakan sebagai sumber pendanaan usaha. Semakin besar Debt to Equity Ratio menandakan kinerja perusahaan buruk. Dimana perusahaan memanfaatkan hutang jangka panjang sebagai pendanaan usahanya. Sehingga mengakibatkan semakin besar risiko yang harus ditanggung investor. Semakin besar Debt to Equity Ratio perusahaan akan mengakibatkan return saham yang diterima kecil, artinya Debt to Equity Ratio berpengaruh negatif terhadap return saham.

\section{Pengaruh Return On Asset terhadap Return Saham}

Return On Assets (ROA) merupakan ukuran kemampuan perusahaan didalam menghasilkan keuntungan (return) bagi perusahaan dengan memanfaatkan aktiva yang dimilikinya. Nilai ROA yang semakin tinggi menunjukkan suatu perusahaan semakin efisien dalam memanfaatkan aktivanya untuk memperoleh laba, sehingga nilai perusahaan meningkat (Brigham, 2001). Jadi semakin tinggi nilai ROA menunjukkan kinerja keuangan perusahaan semakin baik.

ROA merupakan salah satu aspek yang menjadi penilaian emiten untuk menghasilkan laba meningkat maka harga saham perusahaan akan meningkat. Semakin produktif aktiva perusahaan dalam menghasilkan keuntungan maka akan semakin tinggi pula harga saham perusahaan tersebut. Dengan semakin tinggi harga saham maka return saham juga akan semakin tinggi. 
Pribawanti (2007) dalam penelitiannya pada perusahaan manufaktur yang terdaftar di Bursa Efek Jakarta menunjukkan ROA berpengaruh signifikan terhadap return saham. Dimana ROA yang semakin besar menunjukkan kinerja perusahaan yang semakin besar yang berakibat pada peningkatan return saham.

\section{E. Pengaruh Earning Per share terhadap Return Saham}

EPS merupakan rasio yang menunjukkan berapa besar keuntungan (return) yang diperoleh investor atau pemegang saham per lembar saham (Darmaji,2001 :139). EPS dianggap sebagai alat ukur kinerja keuangan suatu perusahaan yang penting bagi manajemen dan investor. Peningkatan EPS menandakan perusahaan berhasil meningkatkan taraf kemakmuran investor untuk menambah jumlah modal yang ditanam pada perusahaan. Apabila perusahaan mampu meningkatkan laba untuk tiap lembar sahamnya, maka investor menganggap bahwa perusahaan dapat memberikan deviden perlembar saham yang besar. Hal ini menambah tingkat kepercayaan investor kepada perusahaan. Kepercayaan investor kepada emiten selalu dibarengi dengan permintaan akan saham emiten. Apabila permintaan saham naik maka harga sahampun meningkat.maka return saham akan meningkat.

Hasil penelitian Artatik (2007) menunjukkan bahwa EPS berpengaruh dan hasilnya positif terhadap return saham. Semakin tinggi nilai EPS berarti semakin baik karena perusahaan mempunyai laba yang tinggi. Perusahaan mempunyai EPS yang tinggi akan menarik banyak investor untuk berinvestasi karena EPS menandakan laba yang berhak didapatkan oleh pemegang saham atas satu lembar saham yang dimilikinya. Sehingga semakin tinggi EPS berarti semakin tinggi return

saham dan sebaliknya semakin rendah EPS semakin rendah pula return saham yang diterima investor.

\section{F. Pengaruh Price Earning Ratio terhadap Return Saham}

Price earning ratio (PER) membandingkan antara harga saham yang diperoleh dari pasar modal dengan laba per lembar saham yang diperoleh pemilik perusahaan (Husnan dan Pudjiastuti, 2006:75). PER merupakan rasio pasar yang digunakan investor untuk memprediksi kemampuan perusahaan dalam menghasilkan laba earning power di masa yang akan datang. Perusahaan dengan tingkat pertumbuhan tinggi biasanya PER tinggi pula, hal ini menunjukan bahwa pasar mengharapkan pertumbuhan laba di masa mendatang. Sebaliknya perusahaan dengan tingkat pertumbuhan rendah cenderung mempunyai PER rendah pula (Prastowo dan Juliaty, 2002 : 96). PER menunjukan perusahaan-perusahaan yang dipercaya oleh pasar akan mencapai tingkat pertumbuhan laba yang tinggi, cenderung akan dinilai lebih tinggi daripada perusahaan-perusahaan yang menunjukkan tingkat pertumbuhan laba yang lebih rendah. Semakin rendah nilai PER suatu saham maka semakin baik atau murah harganya untuk diinvestasikan. PER menjadi rendah nilainya bisa karena harga saham cenderung menurun atau karena meningkatnya laba bersih perusahaan. Jadi semakin kecil nilai PER maka semakin murah saham tersebut untuk dibeli dan semakin baik pula kinerja per-lembar saham dalam menghasilkan laba bagi perusahaan.semakin baik kinerja per lembar saham akan mempengaruhi banyak investor untuk membeli saham tersebut.

Artatik (2007) dan Francisca (2008) mengadakan penelitian mengenai price earning ratio terhadap return saham. Hasil penelitian ini menunjukan bahwa PER tidak signifikan dan hasilnya negatif terhadap return saham, ini berarti semakin tinggi PER maka semakin rendah return saham dan sebaliknya semakin rendah PER maka semakin tinggi return saham yang akan diterima oleh Investor.

\section{METODE PENELITIAN}

\section{A. Jenis dan Sumber Data}

Pengaruh Inventory Turnover (ITO), Debt To Equity Ratio (DER), Return On Asset (ROA), Earning 33 Pershare (EPS), dan Price Earning Ratio (PER) Terhadap Return Saham pada Perusahaan 
Dalam penelitian ini digunakan data sekunder yaitu data yang diperoleh melalui studi pustaka dengan mempelajari berbagai tulisan yang berhubungan dengan Inventory Turnover, Debt to Equity Ratio, Return On Asset, Earning Per Share, dan Price Earning Ratio dan Return Saham.

\section{B. Tehnik Pengumpulan Data}

Dalam penelitian ini digunakan data sekunder yaitu Laporan Keuangan Perusahaan Food and Beverage yang terdaftar di Bursa Efek Indonesia periode 2012-2016 yang dapat diakses melalui internet.

\section{Populasi dan Sampel}

Populasi dalam penelitian ini adalah seluruh Perusahaan Food and Beverage yang terdaftar di Bursa Efek Indonesia periode 2012-2016 sesuai dengan pengklasifikasian Indonesia Capital Market Directory.

Metode pengambilan sampel yang digunakan adalah non probability sampling dengan tehnik purposive sampling, dengan mengambil sampel berdasarkan kriteria, maksud dan tujuan penelitian. Kriteria sampel adalah sebagai berikut : (1). Perusahaan yang dipilih adalah Perusahaan Food and Beverage yang telah go public di Bursa Efek Indonesia selama periode tahun 2012 sampai tahun 2016 yang sahamnya aktif diperdagangkan di BEI; (2). Perusahaan Food and Beverage yang telah menerbitkan laporan keuangan yang lengkap yang telah diaudit pada Bursa Efek Indonesia selama periode tahun 2013 sampai tahun 2017; (3). Perusahaan Food and Beverage yang mempunyai laba positif selama periode tahun 2012 sampai tahun 2016.

Berdasarkan kriteria tersebut, maka jumlah perusahaan yang akan dijadikan sampel adalah 10 Perusahaan Food and Beverage, yaitu: PT. Akasha Wira International Tbk (ADES), PT. Tiga Pilar Sejahtera Food Tbk (AISA), PT. Cahaya Kalbar Tbk (CEKA), PT. Multi Bintang Indonesia Tbk (MLBI), PT. Multi Bintang Indonesia Tbk (MLBI), PT. Sekar Laut Tbk (SKLT), PT. Ultrajaya Milk Industry and Trading Company Tbk (ULTJ), PT. Prashida Aneka Niaga Tbk (PSDN), PT. Indofood Sukses Makmur Tbk (INDF), PT. Delta Djakarta Tbk (DLTA), dan PT. Mayora Indah Tbk (MYOR).

\section{Operasionalisasi Variabel}

Terdapat 6 (enam) variabel yang digunakan dalam penelitian ini, terdiri dari 5 (lima) variabel independent dan 1 (satu) variabel dependent meliputi :

a. Inventory Turnover adalah tingkat perputaran persediaan pada suatu perusahaan yang ditunjukkan melalui perbandingan antara penjualan dengan persediaan dalam satu periode. Inventory Turnover dapat dihitung dengan menggunakan rumus sebagai berikut : Harga Penjualan Penjualan

Rata-rata Persediaan

b. Debt to Equity Ratio (DER) menggambarkan perbandingan antara total utang dengan total ekuitas perusahaan yang digunakan sebagai sumber pendanaan usaha yang diukur dari : Total Kewajiban

Modal Sendiri

c. Return On Asset (ROA) merupakan kemampuan perusahaan memanfaatkan aktivanya untuk memperoleh laba yang diukur dari : Laba Bersih

d. Earning Per Share (EPS) menunjukkan berapa besar keuntungan (return)yang diperoleh investor atau pemegang saham per lembar saham yang dikur dari :

$$
\text { Laba Bersih-Deviden Saham Istimewa }
$$

Rata-rata Tertimbang Jumlah Lembar Saham Biasa yang Beredar

e. Price Earning Ratio membandingkan antara harga saham yang diperoleh dari pasar modal dengan laba per lembar saham yang diperoleh pemilik perusahaan yang diukur dari : 
f. Return Saham merupakan tingkat keuntungan yang akan diperoleh oleh investor yang menanamkan dananya di pasar modal yang diukur dari :

$\mathrm{R}_{\mathrm{it}}=\frac{P_{i t-P_{(t-1)}}}{P i_{(t-1)}}$

Keterangan :

$\mathrm{R}_{\mathrm{it}}$ : Return saham i waktu ke $\mathrm{t}$

$P_{i t}$ : Harga saham i waktu ke $t$

$\mathrm{Pi}_{(\mathrm{t}-1)}$ : Harga saham i waktu ke $\mathrm{t}-\mathrm{i}$

\section{E. Tehnik Analisis}

Data dalam penelitian ini dianalisis dengan menggunakan regresi linier berganda. Persamaan regresi dalam penelitian ini adalah :

$Y=a+b 1 X_{1}+b 2 X_{2}+b 3 X_{3}+b 4 X_{4}+b 5 X_{5}+e$.

Keterangan :

$\mathrm{Y}:$ Return saham

a : Konstanta

$\mathrm{X}_{1}$ : Inventory Turnover

$\mathrm{X}_{2}$ : Debt to Equity Ratio

$\mathrm{X}_{3}$ : Return On Asset

$\mathrm{X}_{4}$ : Earning Pershare

$\mathrm{X}_{5}$ : Price Earning Ratio

$b_{1}, b_{2}, \ldots b_{5}=$ Koefisien regresi parsial untuk masing-masing variabel $X_{1}$,

$\mathrm{X}_{2}, \mathrm{X}_{3}, \mathrm{X}_{4}$, dan $\mathrm{X}_{5}$.

e : residual (faktor pengganggu)

\section{F. Uji Asumsi Klasik}

Uji asumsi klasik dilakukan untuk mengetahui kondisi data yang ada agar dapat menentukan model analisis yang paling tepat digunakan. Uji asumsi klasik yang digunakan dalam penelitian ini terdiri dari uji normalitas dengan menggunakan grafik normal probability plots, uji autokorelasi dengan menggunakan Durbin-Watson statistik, uji multikolinearitas dengan menggunakan Variance Inflation Factors (VIF) serta uji heteroskdastisitas dengan menggunakan uji Glejser.Menurut Ghozali (2001).

\section{a. Uji Normalitas.}

Uji normalitas bertujuan untuk mengetahui apakah variabel residual memiliki distribusi normal. Untuk menguji normalitas, penelitian ini menggunakan grafik normal probability plots. Jika titik-titik menyebar berhimpit di sekitar diagonal dan hal ini menunjukkan bahwa residual terdistribusi secara normal.

\section{b. Uji Autokorelasi.}

Ghozali (2005) menyatakan bahwa uji autokorelasi adalah sebuah pengujian yang bertujuan untuk menguji apakah di dalam model regresi ada korelasi antara kesalahan penggangu pada periode $\mathrm{t}$ dengan kesalahan pengangu pada periode $\mathrm{t}-1$. jika terjadi korelasi bama dinamakan problem autokorelasi. Autokorelasi terjadi karena observasi yang berurutan sepanjang waktu berkaitan satu sama lainnya. Autokorelasi diuji dengan menggunakan Durbin-Watson.

c. Uji Multikolinieritas.

Uji multikolinearitas bertujuan untuk menguji apakah dalam model regresi ditemukan adanya korelasi antar variabel bebas/independen. Jika variabel independen saling korelasi, maka variebel-variebel ini tidak ortogonal. Variabel ortogonal adalah variabel independen yang nilai korelasi antar sesama variabel independen yang lainnya sama dengan nol.uji multikolinearitas dilakukan dengan melihat tolerance value dan value-inflating factor (VIF). Nilai yang umum dipakai adalah tolerance value 0,10 dan VIF lebih kecil dari 10. 


\section{d. Uji Heteroskedastisitas.}

Ghozali (2005) menyatakan bahwa uji heteroskedastisitas dilakukan untuk menguji apakah dalam model regresi terjadi ketidaksamaan variance dari residual suatu pengamatan ke pengamatan lain.model regresi yang baik adalah yang homokedastisitas atau tidak heterosdastisitas. Heteroskedastisitas dalam penelitian ini di uji dengan menggunakan uji scatterplot. Ada atau tidaknya heteroskedastisitas dapat dilakukan dengan melihat ada atau tidaknya pola tertentu pada grafik scatterplot antara SRESID dan ZPRED dimana sumbu $Y$ adalah $Y$ yang diprediksi dan sumbu $X$ adalah residual. Jika ada pola tertentu, seperti titik-titik yang ada membentuk pola tertentu (bergelombang,melebar kemudian menyempit) maka mengindikasikan telah terjadi heteroskedastisitas. Jika tidak ada pola yang teleh dan titik menyebar di atas dan di bawah angka 0 maka tidak terjadi heteroskedastisitas.

\section{G. Uji Hipotesis}

Setelah dilakukan uji asumsi klasik maka tehnik analisis regresi dapat dilakukan dengan melakukan pengujian hipotesis. Pengujian hipotesis dilakukan dengan uji $\mathrm{F}$ untuk pengujian secara simultan dengan kriteria sebagai berikut : $H_{0}$ ditolak jika $F_{\text {hit }}>F_{\text {tabel }}$ dan tidak ditolak jika $F_{\text {hit }}<F_{\text {tabel }}$. Sedangkan uji t digunakan untuk pengujian secara parsial dengan criteria sebagai berikut : $H_{0}$ ditolak jika $t_{\text {hit }}>t_{\text {tabel }}$ dan tidak ditolak jika $t_{\text {hit }}<t_{\text {tabel }}$.

\section{HASIL DAN PEMBAHASAN}

\section{A. Analisis Statistik Deskriptif}

Hasil analisis statistik deskriptif untuk variabel-variabel penelitian tersebut disajikan pada Tabel 1 berikut:

Tabel 1. Descriptive Statistics

\begin{tabular}{|l|r|r|r|r|r|}
\hline & N & Minimum & Maximum & \multicolumn{1}{c|}{ Mean } & Std. Deviation \\
\hline ITO & 60 & 1.23 & 45.01 & 6.1123 & 5.91394 \\
DER & 60 & .20 & 8.44 & 1.2723 & 1.14864 \\
ROA & 60 & -16.56 & 66.91 & 14.4170 & 14.87631 \\
EPS & 60 & -25.78 & 56593.00 & 3670.4193 & 9182.63685 \\
PER & 60 & -8.73 & 39.98 & 14.4853 & 8.45726 \\
RETURN & 60 & -69.18 & 294.74 & 63.2755 & 95.25223 \\
Valid N (listwise) & 60 & & & & \\
\hline
\end{tabular}

Sumber: Output SPSS 18

Berdasarkan hasil perhitungan pada Tabel 1. tersebut terlihat bahwa dari 10 perusahaan sampel dengan 60 obyek pengamatan, rata-rata return selama periode pengamatan (2012-2016) sebesar 63,2755\% dengan standar deviasi (SD) sebesar 95,25223\%. Pada variabel ITO nilai rata-rata selama periode pengamatan sebesar 6,1123 dengan standar deviasi sebesar 5,91394; hasil tersebut menunjukkan bahwa nilai SD lebih kecil daripada rata-rata ITO. Hasil yang sama juga terlihat pada variabel DER, dan PER. Pada variabel EPS standar deviasinya jauh berada di atas rata-rata, ini mengindikasikan hasil yang terdistribusi baik.

Tabel 2. Return Saham Perusahaan dalam Persentase (\%)

\begin{tabular}{|c|c|c|c|c|c|c|c|c|c|}
\hline \multirow[t]{2}{*}{ Emiten } & \multicolumn{6}{|c|}{ Tahun } & \multirow[t]{2}{*}{ Mean } & \multirow[t]{2}{*}{ Max. } & \multirow[t]{2}{*}{ Min. } \\
\hline & 2012 & 2013 & 2014 & 2015 & 2016 & 2017 & & & \\
\hline ADES & $-69,18$ & 184,44 & 153,13 & $-37,65$ & 90,10 & 4,17 & 54,17 & 184,44 & $-69,18$ \\
\hline AISA & $-43,33$ & $-15,29$ & 116,67 & $-34,87$ & 127,40 & 32,41 & 30,50 & 127,40 & $-43,33$ \\
\hline CEKA & -10 & 98,41 & $-12,00$ & $-13,64$ & 36,84 & 35,09 & 22,45 & 98,41 & $-13,64$ \\
\hline MLBI & 12,17 & 290,20 & 55,35 & 30,58 & 113,13 & 143,58 & 107,50 & 290,20 & 12,17 \\
\hline
\end{tabular}


Volume 19 Nomor 1

\begin{tabular}{|c|c|c|c|c|c|c|c|c|c|}
\hline \multirow[t]{2}{*}{ Emiten } & \multicolumn{6}{|c|}{ Tahun } & \multirow[t]{2}{*}{ Mean } & \multirow[t]{2}{*}{ Max. } & \multirow[t]{2}{*}{ Min. } \\
\hline & 2012 & 2013 & 2014 & 2015 & 2016 & 2017 & & & \\
\hline SKLT & 47,54 & 66,67 & $-5,33$ & 1,43 & 28,83 & 0 & 23,19 & 66,67 & $-5,33$ \\
\hline ULTJ & 23,08 & $-27,50$ & 108,62 & $-9,92$ & 23,15 & 238,35 & 59,30 & 238,35 & $-27,50$ \\
\hline PSDN & 135,29 & 23.33 & $-45,95$ & 287,5 & $-33,87$ & $-26,83$ & 56,58 & 287,50 & $-45,95$ \\
\hline INDF & $-62,06$ & 291,72 & 41,07 & $-2,05$ & 60,51 & 36,98 & 61,03 & 291,72 & $-62,06$ \\
\hline DLTA & 62,07 & 257,50 & 110,48 & 2,08 & 214,99 & 120,06 & 127,86 & 257,50 & 2,08 \\
\hline MYOR & $-20,67$ & 294,74 & 138,89 & 33,77 & 64,35 & 30 & 90,18 & 294,74 & $-20,67$ \\
\hline Mean & 7,49 & 146,42 & 66,09 & 25,72 & 72,54 & 61,38 & 63,28 & & \\
\hline Max & 135,29 & 294,74 & 153,13 & 287,5 & 214,99 & 238,35 & & & \\
\hline Min & $-69,18$ & $-27,50$ & $-45,95$ & $-37,65$ & $-33,87$ & $-26,83$ & & & \\
\hline
\end{tabular}

Sumber: Data diolah, 2018

Dari pengamatan Tabel 2 dapat diketahui bahwa perusahaan Food and Beverage yang memiliki nilai return saham tertinggi pada tahun 2012-2017 adalah PT. Mayora Indah Tbk (MYOR) di tahun 2013 sebesar 294,74\% yang menunjukkan bahwa setiap rupiah yang diinvestasikan akan mendapatkan 2,9474 $(\mathrm{Rp} 1,00)=\mathrm{Rp2,9474}$. Sedangkan perusahaan Food and Beverage yang memiliki nilai return saham terendah dari tahun 2012-2017 adalah PT. Akasha Wira International Tbk (ADES) di tahun 2012 sebesar $-69,18 \%$ artinya setiap rupiah yang diinvestasikan akan mengalami kerugian sebesar Rp. 0,6918. Sementara itu total rata-rata return saham seluruh perusahaan sampel selama tahun pengamatan adalah sebesar $63,28 \%$ yang mana nilai rata-rata return saham dari tahun 2012 sampai tahun 2017 mengalami peningkatan dan penurunan yang sangat signifikan setiap tahunnya.

Tabel 3. Inventory Turn Over Perusahaan

\begin{tabular}{|c|c|c|c|c|c|c|c|c|c|}
\hline \multirow[t]{2}{*}{ Emiten } & \multicolumn{6}{|c|}{ Tahun } & \multirow{2}{*}{$\begin{array}{l}\text { Mea } \\
\text { n }\end{array}$} & \multirow[t]{2}{*}{ Max. } & \multirow[t]{2}{*}{ Min. } \\
\hline & 2012 & 2013 & 2014 & 2015 & 2016 & 2017 & & & \\
\hline ADES & 9.8 & 12.14 & 16.29 & 4.75 & 2.74 & 2.61 & 8.06 & 16.29 & 2.61 \\
\hline AISA & 1.72 & 1.62 & 41.23 & 4.01 & 3.55 & 3.07 & 2.53 & 4.01 & 1.23 \\
\hline CEKA & 14.95 & 9.2 & 1.4 & 2.66 & 3.07 & 6.31 & 6.27 & 14.95 & 1.4 \\
\hline MLBI & 6.65 & 6.94 & 7.53 & 7.29 & 4.92 & 7.9 & 6.87 & 7.9 & 4.92 \\
\hline SKLT & 5.88 & 4.93 & 5.08 & 5.75 & 5.11 & 6.28 & 5.51 & 6.28 & 4.93 \\
\hline ULTJ & 3.88 & 3.11 & 3.6 & 4.01 & 5.71 & 4.57 & 4.15 & 5.71 & 3.11 \\
\hline PSDN & 8.27 & 4.56 & 5.37 & 6.87 & 5.07 & 5.07 & 5.87 & 8.27 & 4.56 \\
\hline INDF & 4.92 & 5.27 & 4.59 & 45.01 & 4.69 & 5.32 & 11.63 & 45.01 & 4.59 \\
\hline DLTA & 5.28 & 6.03 & 2.26 & 2.03 & 1.91 & 1.52 & 3.17 & 6.03 & 1.52 \\
\hline MYOR & 5.9 & 7.94 & 11.07 & 5.83 & 5.45 & 6.25 & 7.07 & 11.07 & 5.45 \\
\hline Mean & 6.73 & 6.17 & 5.84 & 8.82 & 4.22 & 4.89 & 6.11 & & \\
\hline $\operatorname{Max}$ & 14.95 & 12.14 & 16.29 & 45.01 & 5.71 & 7.90 & & & \\
\hline Min & 1.72 & 1.62 & 1.23 & 2.03 & 1.91 & 1.52 & & & \\
\hline
\end{tabular}

Sumber: Data diolah, 2018

Berdasarkan Tabel 3 perusahaan Food and Beverages yang memiliki perputaran persediaan (inventory turn over) yang paling tinggi pada tahun 2012-2017 adalah PT Indofood Sukses Makmur, Tbk (INDF) yaitu sebesar 45,01 kali dalam setahun di tahun 2015 artinya kemampuan perusahaan dalam mengkonversi persediaan menjadi penjualan adalah sebanyak 45,01 kali. Ini menandakan INDF memiliki penjualan yang lancar pada tahun tersebut. Sedangkan perusahaan yang paling sedikit mengalami perputaran persediaan adalah PT Tiga Pilar Sejahtera Food, Tbk (AISA) di tahun 2014 yaitu sebanyak 1,23 kali yang artinya AISA hanya mampu mengubah persediaannya menjadi penjualan sebanyak 1,23 kali dalam tahun 
tersebut. Sementara itu total rata-rata inventory turnover seluruh perusahaan sampel selama tahun pengamatan adalah sebesar 6,11 kali.

Tabel 4. Debt To Equity Ratio

\begin{tabular}{|c|c|c|c|c|c|c|c|c|c|}
\hline \multirow[t]{2}{*}{ Emiten } & \multicolumn{6}{|c|}{ Tahun } & \multirow[t]{2}{*}{ Mean } & \multirow[t]{2}{*}{ Max. } & \multirow[t]{2}{*}{ Min. } \\
\hline & 2012 & 2013 & 2014 & 2015 & 2016 & 2017 & & & \\
\hline ADES & 2.56 & 1.61 & 2.25 & 1.51 & 0.86 & 0.41 & 1.53 & 2.56 & 0.41 \\
\hline AISA & 1.60 & 2.14 & 2.34 & 0.96 & 0.90 & 1.13 & 1.51 & 2.34 & 0.90 \\
\hline CEKA & 1.45 & 0.89 & 1.75 & 1.03 & 1.22 & 1.02 & 1.23 & 1.75 & 0.89 \\
\hline MLBI & 1.73 & 8.44 & 1.41 & 1.30 & 2.49 & 0.80 & 2.70 & 8.44 & 0.80 \\
\hline SKLT & 1.00 & 0.73 & 0.69 & 0.74 & 0.93 & 1.16 & 0.88 & 1.16 & 0.69 \\
\hline ULTJ & 0.53 & 0.45 & 0.54 & 0.55 & 0.44 & 0.40 & 0.49 & 0.55 & 0.40 \\
\hline PSDN & 1.63 & 1.44 & 1.60 & 1.04 & 0.67 & 0.63 & 1.17 & 1.63 & 0.63 \\
\hline INDF & 3.11 & 2.45 & 1.34 & 0.70 & 0.74 & 1.04 & 1.56 & 3.11 & 0.70 \\
\hline DLTA & 0.34 & 0.27 & 0.20 & 0.22 & 0.25 & 0.28 & 0.26 & 0.34 & 0.20 \\
\hline MYOR & 1.32 & 1.03 & 1.18 & 1.72 & 1.71 & 1.47 & 1.41 & 1.72 & 1.03 \\
\hline Mean & 1.53 & 1.95 & 1.33 & 0.98 & 1.02 & 0.83 & 1.27 & & \\
\hline $\operatorname{Max}$ & 3.11 & 8.44 & 2.34 & 1.72 & 2.49 & 1.47 & & & \\
\hline Min & 0.34 & 0.27 & 0.20 & 0.22 & 0.25 & 0.28 & & & \\
\hline
\end{tabular}

Sumber: Data diolah, 2018

Berdasarkan Tabel 4, dapat dilihat bahwa pada periode pengamatan 2012-2017 perusahaan dengan penggunaan hutang tertinggi adalah PT. Multi Bintang Indonesia Tbk (MLBI) dengan nilai sebesar 8,44. Artinya sebesar penggunaan hutang sebagai pendanaan bagi perusahaan sebesar 8,44 kali dari modal perusahaan. Sedangkan nilai DER terendah dimiliki oleh PT Delta Djakarta Tbk (DLTA), yaitu sebesar 0,2 artinya dari seluruh modal perusahaan hanya sebesar $20 \%$ saja yang dibiayai oleh hutang. Rata-rata perusahaan sampel memiliki DER sebesar 1,27 pada periode pengamatan.

Tabel 5. Return On Asset Perusahaan dalam Persentase (\%)

\begin{tabular}{|c|c|c|c|c|c|c|c|c|c|}
\hline \multirow[t]{2}{*}{ Emiten } & \multicolumn{6}{|c|}{ Tahun } & \multirow[t]{2}{*}{ Mean } & \multirow[t]{2}{*}{ Max. } & \multirow[t]{2}{*}{ Min. } \\
\hline & 2012 & 2013 & 2014 & 2015 & 2016 & 2017 & & & \\
\hline ADES & $-8,22$ & 9,15 & 9,76 & 9,37 & 8,18 & 12,62 & 6,81 & 12,62 & $-8,22$ \\
\hline AISA & 2,82 & 2,81 & 4,13 & 4,18 & 6,56 & 6,91 & 4,57 & 6,91 & 2,81 \\
\hline CEKA & 6,97 & 8,71 & 3,48 & 11,7 & 5,68 & 6,06 & 7,10 & 11,70 & 3,48 \\
\hline MLBI & 23,61 & 34,27 & 38,96 & 41,56 & 39,36 & 66,91 & 40,78 & 66,91 & 23,61 \\
\hline SKLT & 2,12 & 6,53 & 2,42 & 2,79 & 3,19 & 3,79 & 3,47 & 6,53 & 2,12 \\
\hline ULTJ & 17,67 & 3,53 & 5,34 & 5,89 & 14,6 & 11,56 & 9,77 & 17,67 & 3,53 \\
\hline PSDN & 3,29 & 9,18 & 6,19 & 5,66 & 3,75 & 3,13 & 4,40 & 6,19 & 3,13 \\
\hline INDF & 2.61 & 5.14 & 8,50 & 9,36 & 8,21 & 6,61 & 6,74 & 9,36 & 2,61 \\
\hline DLTA & 11,99 & 16,64 & 20,61 & 21,79 & 28,64 & 31,2 & 21,81 & 31,20 & 11,99 \\
\hline MYOR & 6,71 & 11,46 & 14,97 & 9,49 & 8,97 & 10,85 & 10,41 & 14,97 & 6,71 \\
\hline Mean & 6,96 & 10,92 & 11,44 & 12,18 & 12,71 & 15,96 & 11,59 & & \\
\hline Max & 23,61 & 34,27 & 38,96 & 41,56 & 39,36 & 66,91 & & & \\
\hline Min & $-8,22$ & 2,81 & 2,42 & 2,79 & 3,19 & 3,13 & & & \\
\hline
\end{tabular}

Sumber: Data diolah, 2018

Dari Tabel 5 dapat diketahui bahwa nilai rata-rata ROA yang diperoleh perusahaan mengalami peningkatan dan penurunan yang tidak signifikan, dengan total rata-rata selama tahun pengamatan periode $2012-2017$ sebesar $11,59 \%$. Nilai ROA yang tertinggi dari tahun 
2012-2017 dimiliki oleh PT. Multi Bintang Indonesia Tbk (MLBI) dengan nilai yang paling tinggi di tahun 2017 sebesar 66,91\% yang artinya perusahaan mendapatkan pengembalian sebesar $66,91 \%$ untuk aktiva-aktiva yang dimiliki. Sedangkan nilai ROA terendah selama tahun pengamatan periode 2012-2017 dimiliki oleh PT. Akasha Wira International Tbk (ADES), dengan nilai paling rendah pada tahun 2012 sebesar $-8,22 \%$ yang artinya perusahaan mendapatkan kerugian sebesar $8,22 \%$ untuk aktiva-aktiva yang dimiliki.

Tabel 6. Earning Per Share (EPS) dalam Rupiah (Rp)

\begin{tabular}{|c|c|c|c|c|c|c|c|c|c|}
\hline \multirow{2}{*}{ Emiten } & \multicolumn{6}{|c|}{ Tahun } & \multirow{2}{*}{ Mean } & \multirow{2}{*}{ Max. } & \multirow{2}{*}{ Min. } \\
\hline & 2012 & 2013 & 2014 & 2015 & 2016 & 2017 & & & \\
\hline ADES & $-25,78$ & 27,67 & 53,67 & 43,85 & 141,34 & 94 & 55,79 & $\begin{array}{c}141,3 \\
4\end{array}$ & $-25,78$ \\
\hline AISA & 17,16 & 22,60 & 45,00 & 89,68 & 72,18 & 119 & 60,94 & 119 & 17,16 \\
\hline CEKA & 93,67 & 166,26 & 99,37 & 323,72 & 196,12 & 218 & 182,86 & 32372 & 93.67 \\
\hline MLBI & 10550,88 & $\begin{array}{c}16158,4 \\
2\end{array}$ & $\begin{array}{c}21021 \\
17\end{array}$ & $\begin{array}{c}24080 \\
78\end{array}$ & $\begin{array}{c}21518 \\
98\end{array}$ & 56593 & $\begin{array}{c}24987 \\
21\end{array}$ & 56593 & $\begin{array}{c}10550,8 \\
8\end{array}$ \\
\hline SKLT & 6,18 & 18,53 & 7.00 & 8,65 & 11,53 & 17 & 11,48 & 18,53 & 6,18 \\
\hline ULTJ & 105,15 & 21,17 & 37,09 & 35,08 & 122,36 & 113 & 72,31 & $\begin{array}{c}122,3 \\
6\end{array}$ & 21,17 \\
\hline PSDN & 6,56 & 22,53 & 8,97 & 16,57 & 17,79 & 15 & 14,57 & 22,53 & 6,56 \\
\hline INDF & 117,81 & 236,42 & 336,3 & 571,43 & 371,41 & 588 & 370,23 & 588 & 117,81 \\
\hline DLTA & 5230,34 & 7900 & $\begin{array}{c}8715,1 \\
3\end{array}$ & $\begin{array}{c}9474,3 \\
9\end{array}$ & $\begin{array}{c}13327 \\
84\end{array}$ & 16892 & $\begin{array}{c}10256, \\
62\end{array}$ & 16892 & 5230,34 \\
\hline MYOR & 255,98 & 485,48 & 631,48 & 631,15 & 971,10 & 1178 & 692,20 & 1178 & 255,98 \\
\hline Mean & 1635,8 & 2505,91 & $\begin{array}{c}3095,5 \\
2\end{array}$ & $\begin{array}{c}3527,5 \\
3\end{array}$ & $\begin{array}{c}3675,0 \\
7\end{array}$ & $\begin{array}{c}7582, \\
7\end{array}$ & $\begin{array}{c}3670,4 \\
2\end{array}$ & & \\
\hline Max & 10550,88 & $\begin{array}{c}16158,4 \\
2\end{array}$ & $\begin{array}{c}21021 \\
17\end{array}$ & $\begin{array}{l}24080 \\
78\end{array}$ & $\begin{array}{c}21518 \\
98\end{array}$ & 56593 & & & \\
\hline Min & $-25,78$ & 18,53 & 75 & 8,65 & 11,53 & 15 & & & \\
\hline
\end{tabular}

Sumber: Data diolah, 2018

Berdasarkan Tabel 6 menunjukkan bahwa nilai rata-rata EPS dari tahun 2012-2017 setiap tahunnya mengalami peningkatan, dengan total rata-rata sebesar Rp. 3.670,42 Sementara itu, nilai EPS tertinggi pada periode pengamatan yang juga mengalami kenaikan setiap tahunnya dimiliki oleh PT. Multi Bintang Indonesia Tbk (MLBI) dengan nilai tertinggi sebesar Rp. 56.593 pada tahun 2017, artinya investor memperoleh keuntungan sebesar Rp. 56.593 per saham yang dimilikinya. Sedangkan nilai EPS terendah dimiliki oleh PT. Akasha Wira International Tbk (ADES), yang mana pada tahun pengamatan periode 2012-2017 mengalami peningkatan dan penurunan dengan nilai terendah pada tahun 2012 yaitu sebesar Rp. $-25,78$ yang artinya investor memperoleh kerugian sebesar Rp. 25,78 per saham yang dimilikinya.

Tabel 7. Price Earning Ratio dalam Persentase (\%)

\begin{tabular}{|c|c|c|c|c|c|c|c|c|c|}
\hline \multirow[t]{2}{*}{ Emiten } & \multicolumn{6}{|c|}{ Tahun } & \multirow[t]{2}{*}{ Mean } & \multirow[t]{2}{*}{ Max. } & \multirow[t]{2}{*}{ Min. } \\
\hline & 2012 & 2013 & 2014 & 2015 & 2016 & 2017 & & & \\
\hline ADES & $-8,73$ & 23,13 & 30,19 & 23,03 & 13,17 & 21,2 & 17,00 & 30,19 & $-8,73$ \\
\hline AISA & 24,69 & 15,93 & 17,19 & 9,66 & 12,11 & 12,06 & 15,27 & 24,69 & 9,66 \\
\hline CEKA & 7,47 & 8,96 & 11,07 & 2,93 & 5,76 & 5,32 & 6,92 & 11,07 & 2,93 \\
\hline MLBI & 4,69 & 10,95 & 13,08 & 14,91 & 20,95 & 21,2 & 14,30 & 21,20 & 4,69 \\
\hline SKLT & 14,56 & 8,09 & 20,01 & 16,18 & 13,61 & 10,87 & 15,14 & 20,01 & 10,87 \\
\hline ULTJ & 7,61 & 27,39 & 32,63 & 30,79 & 16,49 & 39,98 & 25,82 & 39,98 & 7,61 \\
\hline
\end{tabular}

Pengaruh Inventory Turnover (ITO), Debt To Equity Ratio (DER), Return On Asset (ROA), Earning 39 Pershare (EPS), dan Price Earning Ratio (PER) Terhadap Return Saham pada Perusahaan 
Volume 19 Nomor 1

\begin{tabular}{|c|c|c|c|c|c|c|c|c|c|}
\hline \multirow[t]{2}{*}{ Emiten } & \multicolumn{6}{|c|}{ Tahun } & \multirow[t]{2}{*}{ Mean } & \multirow[t]{2}{*}{ Max. } & \multirow[t]{2}{*}{ Min. } \\
\hline & 2012 & 2013 & 2014 & 2015 & 2016 & 2017 & & & \\
\hline PSDN & 15,24 & 4,88 & 8,92 & 18,71 & 6,01 & 10,13 & 10,65 & 18,71 & 4,88 \\
\hline INDF & 7,89 & 15,02 & 14,5 & 8,05 & 10,02 & 11,23 & 11,12 & 15,02 & 7,89 \\
\hline DLTA & 3,82 & 7,85 & 13,77 & 5,88 & 20,4 & 22,5 & 12,37 & 22,50 & 3,82 \\
\hline MYOR & 4,45 & 9,27 & 17,02 & 22,58 & 22,26 & 22,07 & 16,28 & 22,58 & 4,45 \\
\hline Mean & 8,17 & 14.34 & 17,46 & 15,02 & 14,28 & 17,66 & 14,49 & & \\
\hline $\operatorname{Max}$ & 24,69 & 27.39 & 32,63 & 30,79 & 22,26 & 39,98 & & & \\
\hline Min & $-8,73$ & 4.88 & 8,92 & 2,93 & 5,76 & 5,32 & & & \\
\hline
\end{tabular}

Sumber: Data diolah, 2018

Berdasarkan Tabel 7 rata-rata Price Earning Ratio seluruh perusahaan sampel adalah sebesar 14,49 kali. Untuk Price Earning Ratio tertinggi selama tahun 2012-2017 dimiliki oleh PT Ultrajaya Milk Industry and Trading Company, Tbk (ULTJ) di tahun 2017 yaitu sebesar 39,98, artinya harga saham adalah sebesar 39,98 kali laba per lembar saham perusahaan. Sedangkan perusahaan yang memiliki PER terendah adalah PT Akasha Wira International, Tbk (ADES) pada tahun 2012, sebesar $-8,73$, artinya harga saham perusahaan adalah sebesar 8,73 kali dari kerugian per lembar sahamnya.

\section{B. Pengujian Asumsi Klasik}

Hasil Uji Normalitas Data adalah sebagai berikut:

Tabel 8. Hasil Pengujian Normalitas One-Sample Kolmogorov-Smirnov Test

\begin{tabular}{|ll|r|}
\hline & & Unstandardized Residual \\
\hline $\mathrm{N}$ & & 60 \\
Normal Parameters ${ }^{\mathrm{a}, \mathrm{b}}$ & Mean & .0000000 \\
& Std. Deviation & 83.30225220 \\
Most Extreme Differences & Absolute & .105 \\
& Positive & .105 \\
& Negative & -.069 \\
Kolmogorov-Smirnov Z & & .809 \\
Asymp. Sig. (2-tailed) & & .529 \\
\hline
\end{tabular}

a. Test distribution is Normal.

b. Calculated from data.

Sumber: Output SPSS 18

Berdasarkan Tabel 8 pengujian terhadap normalitas dengan menggunakan uji Kolmogorov-Smirnov menunjukkan nilai signifikansi diatas 0,05 yaitu sebesar 0,529. Hal ini berarti data yang ada terdistribusi normal.

Hasil Uji Multikolinearitas adalah sebagai berikut:

Tabel 9. Hasil Perhitungan VIF Coefficientsa

\begin{tabular}{|ll|r|r|}
\hline \multirow{2}{*}{ Model } & \multicolumn{2}{|c|}{$\begin{array}{c}\text { Collinearity } \\
\text { Statistics }\end{array}$} \\
\cline { 3 - 4 } & & Tolerance & \multicolumn{1}{c|}{ VIF } \\
\hline 1 & (Const & & \\
& ant) & & \\
& ITO & .987 & 1.013 \\
& DER & .940 & 1.063 \\
& ROA & .215 & 4.642 \\
& &
\end{tabular}

Pengaruh Inventory Turnover (ITO), Debt To Equity Ratio (DER), Return On Asset (ROA), Earning 40 Pershare (EPS), dan Price Earning Ratio (PER) Terhadap Return Saham pada Perusahaan 


\begin{tabular}{|ll|r|r|}
\hline \multirow{2}{*}{ Mode1 } & \multicolumn{2}{|c|}{$\begin{array}{c}\text { Collinearity } \\
\text { Statistics }\end{array}$} \\
\cline { 2 - 4 } & Tolerance & VIF \\
\cline { 2 - 4 } & EPS & .221 & 4.520 \\
& PER & .962 & 1.039 \\
\hline
\end{tabular}

a. Dependent Variable: RETURN

Sumber: Output SPSS 18; Coefficients diolah

Pada Tabel 9 menunjukkan bahwa keempat variabel independen tidak terjadi multikolinearitas karena nilai VIF $<10$ dan nilai tolerance juga tidak ada yang $<0,1$. Dengan demikian keempat variabel independen tersebut dapat digunakan untuk memprediksi Return Saham selama periode pengamatan.

Uji Heteroskedastisitas adalah sebagai berikut:

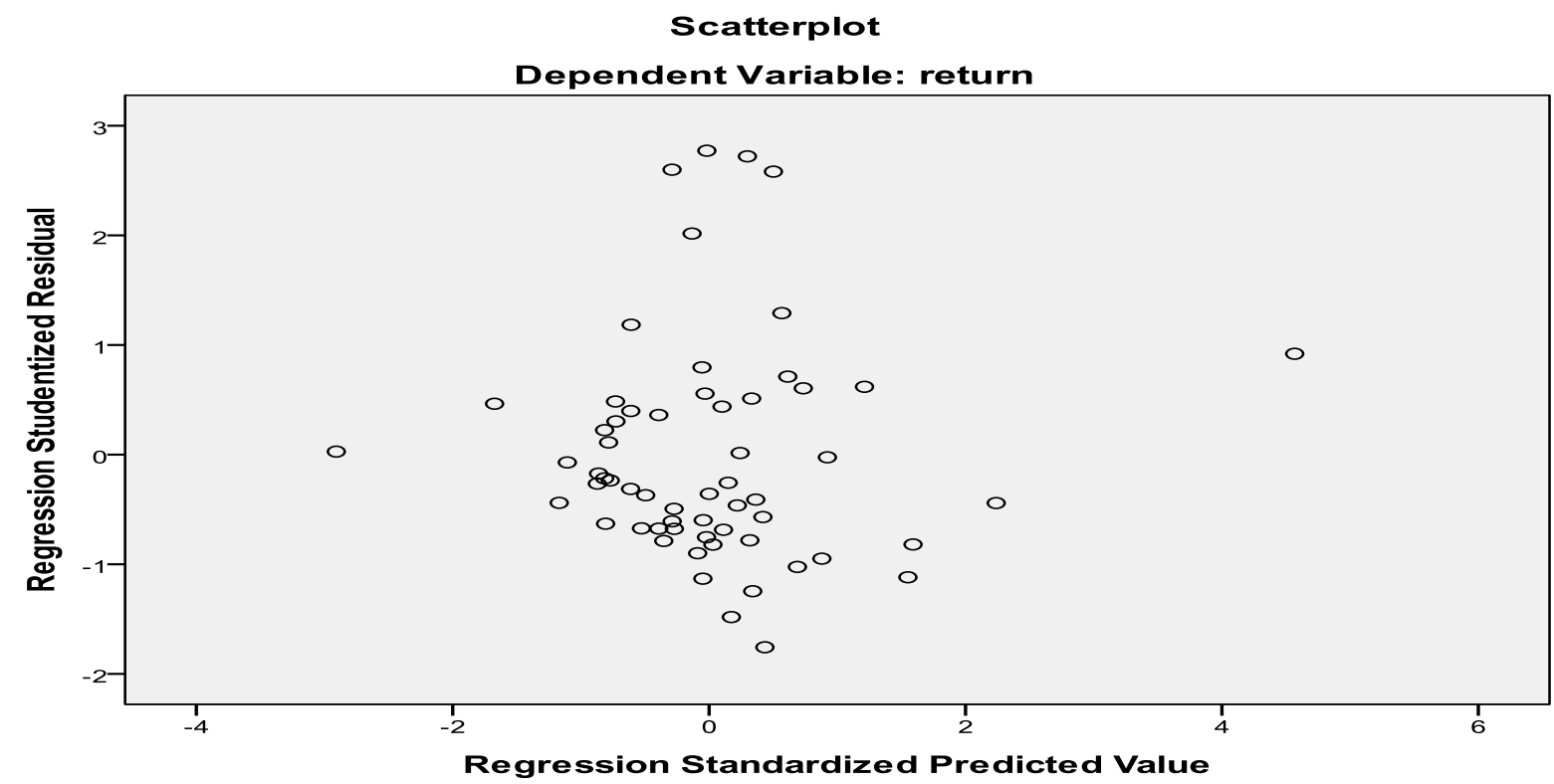

Gambar 1. Hasil Uji Heteroskedastisitas

Hasil uji heteroskedastisitas dari gambar 1 menunjukkan bahwa grafik scatterplot antara SRESID dan ZPRED menunjukan pola penyebaran, dimana titik-titik menyebar di atas dan di bawah 0 pada sumbu Y. Hal ini menunjukkan bahwa tidak terjadi heteroskedastisitas pada data yang akan digunakan.

Hasil Uji Autokorelasi adalah sebagai berikut:

Tabel 10. Hasil Uji Autokorelasi Model Summaryb

\begin{tabular}{|l|c|r|r|r|r|}
\hline Model & $\mathbf{R}$ & $\begin{array}{c}\mathbf{R} \\
\text { Square }\end{array}$ & $\begin{array}{c}\text { Adjusted } \\
\text { R Square }\end{array}$ & $\begin{array}{c}\text { Std. Error of } \\
\text { the Estimate }\end{array}$ & Durbin-Watson \\
\hline dimension0 1 & $.485^{\mathrm{a}}$ & .235 & .164 & 87.07347 & 1.802 \\
\hline
\end{tabular}

a. Predictors: (Constant), ITO,DER, ROA, EPS, PER

b. Dependent Variable: RETURN

Sumber: Output SPSS 18

Berdasarkan hasil analisis regresi diperoleh nilai D-W sebesar 1,802. Sedangkan nilai dU diperoleh sebesar 1,7671. Dengan demikian diperoleh bahwa nilai DW berada diantara dU yaitu 1,7671 dan 4 - dU yaitu 2,2329. Sehingga menunjukkan bahwa model regresi tersebut bebas dari masalah autokorelasi. 
Volume 19 Nomor 1

\section{Pengujian Hipotesis}

Hasil Uji Pengaruh Simultan (Uji F)

Tabel 11. Uji Signifikansi Simultan (uji F)

ANOVA $^{b}$

\begin{tabular}{|c|c|c|c|c|c|c|}
\hline \multicolumn{2}{|c|}{ Model } & Sum of Squares & df & Mean Square & $\mathrm{F}$ & Sig. \\
\hline 1 & Regression & 125889.578 & 5 & 25177.916 & 3.321 & $.011^{\mathrm{a}}$ \\
\hline & Residual & 409416.648 & 54 & 7581.790 & & \\
\hline & Total & 535306.226 & 59 & & & \\
\hline
\end{tabular}

a. Predictors: (Constant), ITO,DER, ROA, EPS, PER

b. Dependent Variable: RETURN

Sumber: Output SPSS 18; Regressions

Dari hasil perhitungan diperoleh nilai $\mathrm{F}$ sebesar 3,321 dan nilai signifikansi sebesar 0,011 . Karena F hitung $(3,321)>\mathrm{F}$ tabel $(2,386)$ dan nilai signifikansi $<0,05$ yaitu sebesar 0,011 maka Ho ditolak dan Hi diterima yang berarti variabel ITO, EPS, DER, ROA, dan PER secara bersama-sama memliki pengaruh yang signifikan terhadap variabel Return Saham atau dengan kata lain model yang digunakan layak (goodness of fit).

\section{Hasil Uji Pengaruh Parsial (Uji t)}

Tabel 12. Uji Signifikansi Parsial (uji t) Coefficientsa

\begin{tabular}{|c|c|c|c|c|c|}
\hline \multirow[t]{2}{*}{ Model } & \multicolumn{2}{|c|}{$\begin{array}{l}\text { Unstandardized } \\
\text { Coefficients }\end{array}$} & \multirow{2}{*}{$\begin{array}{c}\text { Standardized } \\
\text { Coefficients }\end{array}$} & \multirow[b]{2}{*}{$\mathrm{T}$} & \multirow[b]{2}{*}{ Sig. } \\
\hline & $\mathrm{B}$ & Std. Error & & & \\
\hline 1 (Constant) & -42.736 & 31.884 & & -1.340 & .186 \\
\hline ITO & .731 & 1.930 & .045 & .379 & .706 \\
\hline DER & 13.582 & 10.176 & .164 & 1.335 & .188 \\
\hline $\mathrm{ROA}$ & 3.306 & 1.642 & .516 & 2.014 & .049 \\
\hline EPS & -.003 & .003 & -.257 & -1.018 & .313 \\
\hline PER & 3.203 & 1.367 & .284 & 2.344 & .023 \\
\hline
\end{tabular}

a. Dependent Variable: RETURN

Sumber: Output SPSS 18; Regressions

Dari tabel 12 di atas menunjukkan bahwa variabel ROA dan PER berpengaruh signifikan terhadap return saham, sedangkan variabel ITO, DER dan EPS tidak berpengaruh signifikan terhadap return saham.

D. Nilai Koefisien Determinasi

Tabel 13. Uji Koefisien Determinasi Model Summaryb

\begin{tabular}{|r|r|r|r|r|r|}
\hline Model & $\mathbf{R}$ & R Square & $\begin{array}{c}\text { Adjusted R } \\
\text { Square }\end{array}$ & $\begin{array}{c}\text { Std. Error of the } \\
\text { Estimate }\end{array}$ & $\begin{array}{c}\text { Durbin- } \\
\text { Watson }\end{array}$ \\
\hline 1 & .485 & .235 & .164 & 87.07347 & 1.802 \\
\hline
\end{tabular}

a. Predictors: (Constant), ITO,DER, ROA, EPS, PER

b. Dependent Variable: RETURN

Sumber: Output SPSS 18; Regressions

Koefisien determinasi atau Adjusted R square sebesar 0.164 menunjukkan bahwa hanya $16.4 \%$ variasi dari Return Saham yang bisa dijelaskan oleh variasi dari keempat variabel independen variabel ITO, EPS, DER, ROA, dan PER sedangkan sisanya sebesar 83,6\% dijelaskan oleh sebab-sebab lain diluar model.

Pengaruh Inventory Turnover (ITO), Debt To Equity Ratio (DER), Return On Asset (ROA), Earning 42 Pershare (EPS), dan Price Earning Ratio (PER) Terhadap Return Saham pada Perusahaan 


\section{E. Pembahasan}

Dari hasil analisis diperoleh persamaan regresi berganda Return $=-42.736+0,731$

ITO + 13,582 DER + 3,306 ROA - 0,003 EPS + 3,203 PER + e

Hasil pengujian masing-masing variabel independen terhadap variabel dependennya dapat dianalisis sebagai berikut:

\section{F. Variabel Inventory Turn Over (ITO)}

Dari hasil perhitungan uji-t diperoleh nilai $t$ hitung sebesar 0,379 dengan nilai signifikansi sebesar 0,706. Karena nilai t hitung 0,379 lebih kecil dari t-tabel $(1,677)$ dan nilai signifikansi lebih besar dari 0,05 yaitu sebesar 0,706 maka hipotesis 1 ditolak yang berarti ada tidak ada pengaruh yang signifikan secara parsial antara variabel Inventory Turn Over (ITO) dengan variabel Return Saham. Parameter positif pada ITO menunjukkan perubahan (naik/turun) ITO akan mengakibatkan perubahan pada Return Saham perusahaan ke arah yang sama.

Semakin tinggi perputaran persediaan perusahaan (Inventory Turn Over) menunjukkan perusahaan semakin efisien dalam menekan biaya atas persediaan tersebut. Semakin tinggi inventory turnover juga akan semakin baik karena hal ini mengindikasikan penjualan yang lancar sehingga meningkatkan keuntungan. Peningkatan keuntungan ini akan direspon positif oleh investor sehingga harga saham naik dan return saham menjadi meningkat. Hasil penelitian ini mendukung penelitian Wulandari (2012) yang menemukan bahwa ITO berpengaruh positif dan tidak signifikan terhadap return saham.

\section{G. Variabel Debt to Quity Ratio (DER)}

Dari hasil pengolahan data SPSS 18 menunjukkan bahwa DËR berpengaruh positif dan tidak signifikan terhadap return saham di Bursa Efek Indonesia, yaitu dengan nilai koefisien 13,582 dan $t$ hitung $<$ tabel $(1,335<1,677)$ serta nilai signifikansi 0,188 lebih besar 0,05. Hasil penelitian ini mendukung hasil penelitian Wulandari (2012) yang menemukan variabel DER tidak berpengaruh signifikan dan positif terhadap return saham. Hasil penelitian tidak mendukung penelitian Nidianti (2013) yang menemukan DER berpengaruh signifikan dan positif terhadap return saham.

Semakin besar DER menandakan struktur permodalan usaha lebih banyak memanfaatkan hutang-hutang relatif terhadap ekuitas. Penggunaan hutang untuk meningkatkan laba dengan kondisi perekonomian yang baik dapat membawa perusahaan memperoleh laba yang lebih besar dibanding perusahaan yang tidak menggunakan utang dalam membiayai operasi perusahaan. Pada penelitian ini terlihat bahwa beberapa perusahaan sampel yang memiliki rasio hutang yang tinggi memperoleh laba yang juga besar, sebagai contoh PT. Multi Bintang Indonesia Tbk (MLBI). Hal ini tercermin juga dari Return On Asset yang dihasilkan perusahaan yang menandakan perusahaan telah menggunakan pendanaan melalui hutang dengan baik sehingga mampu meningkatkan laba. Sinyal tersebut membuat investor tertarik memiliki saham perusahaan sehingga menaikkan harga saham yang juga akan meningkatkan return saham tersebut. Secara empiris ada hubungan positif antara kebijakan hutang perusahan dengan return saham yang dilihat dari parameter positif pada DER yang menunjukkan perubahan (naik/turun) pada DER akan mengakibatkan perubahan terhadap Return Saham perusahaan ke arah yang sama.

\section{H. Variabel Return On Asset (ROA)}

Dari hasil perhitungan uji-t diperoleh nilai $t$ hitung 2,014 dengan nilai signifikansi sebesar 0,049. Karena nilai t hitung 2,014 lebih besar dari t-tabel $(1,677)$ dan nilai signifikansi lebih kecil dari 0,05 yaitu sebesar 0,049 maka hipotesis 3 diterima berarti ada pengaruh positif yang signifikan antara variabel ROA dengan variabel Return Saham. Hasil penelitian 
ini mendukung penelitian Ulupui (2007) yang menemukan ada pengaruh yang positif dan signifikan antara ROA dan return saham, tetapi tidak mendukung penelitian Nidianti (2013) yang menemukan bahwa ROA tidak berpengaruh signifikan dan negatif terhadap return saham.

Hal ini menunjukkan perusahaan sudah efektif dalam pemanfaatan aktivanya untuk menghasilkan keuntungan sehingga menambah daya tarik investor untuk menanamkan sahamnya dalam perusahaan yang akhirnya berdampak positif terhadap return saham.

\section{Variabel Earning Per Share (EPS)}

Dari hasil perhitungan uji-t diperoleh nilai $t$ hitung 1,018 dengan nilai signifikansi sebesar 0,313. Karena nilai t hitung 1,018 lebih kecil dari t-tabel $(1,677)$ dan nilai signifikansi lebih besar dari 0,05 yaitu sebesar 0,313 maka hipotesis 4 ditolak berarti EPS tidak berpengaruh secara parsial dan negatif terhadap variabel Return Saham. Hasil penelitian ini tidak mendukung penelitian-penelitian sebelumnya seperti oleh Mardianti yang menunjukkan bahwa EPS mempengaruhi return saham secara signifikan dan positif.

Hasil penelitian ini juga kontradiktif dengan teori yang mendasarinya bahwa semakin tingginya EPS menandakan kinerja perusahaan semakin baik karena dapat meningkatkan laba perusahaan yang selanjutnya akan meningkatkan daya tarik perusahaan dimata investor. Tidak signifikannya hasil penelitian ini dikarenakan berdasarkan analisis statistik deskriptif terhadap variabel EPS, terlihat bahwa EPS memiliki distribusi yang kurang baik karena nilai rata-ratanya berada jauh dibawah standar deviasi. Beberapa perusahaan seperti PT. Multi Bintang Indonesia Tbk (MLBI) dan PT Delta Djakarta Tbk (DLTA) membukukan keuntungan yang jauh melebihi rata-rata keuntungan pesaingnya pada sektor yang sama namun saham yang beredar dari kedua perusahaan tersebut jauh dibawah perusahaan lainnya, yang hanya mencapai jutaan lembar sehingga keuntungan per lembar saham menjadi lebih besar dan jauh diatas rata-rata EPS perusahaan dalam industri sejenisnya

\section{J. Variabel Price Earning Ratio (PER)}

Dari hasil perhitungan uji-t diperoleh nilai $\mathrm{t}$ hitung 2,344 dengan nilai signifikansi sebesar 0,023 . Karena nilai t hitung $(2,344)$ lebih besar dari t-tabel $(1,677)$ dan nilai signifikansi lebih kecil dari 0,05 yaitu sebesar 0,023 maka hipotesis 5 diterima berarti ada pengaruh yang signifikan antara variabel PER dengan variabel return saham. Hasil penelitian ini mendukung penelitian Meliana (2004) yang menunjukkan hasil bahwa PER berpengaruh signifikan dan positif terhadap return saham. Tetapi, hasil penelitian ini tidak konsisten dengan penelitian yang dilakukan oleh Anugerah dan Kadir (2001) yang menyatakan adanya korelasi negatif antara return dan PER. Adanya pengaruh positif antara return dan PER, menunjukkan bahwa investor menggunakan data PER yang terdapat dalam laporan keuangan emiten sebagai alat analisis kesehatan suatu saham untuk memperoleh hasil (return) yang layak dari suatu investasi saham. Investor menganggap bahwa semakin besar PER memungkinkan harga pasar dari setiap lembar saham akan semakin baik, dengan begitu investor akan memperoleh return dari perubahan harga saham tersebut (Meliana, 2004).

\section{KESIMPULAN}

Hasil penelitian ini memberikan solusi pengaruh dari kelima variabel independen terhadap Return Saham Dari lima hipotesis yang diajukan hanya terdapat dua (2) hipotesis yang dapat diterima yaitu hipotesis 3 .

1. Secara parsial variabel ITO tidak berpengaruh signifikan terhadap variabel return saham sehingga hipotesis 1 ditolak.

2. Secara parsial variabel DER tidak berpengaruh signifikan terhadap variabel return saham sehingga hipotesis 2 ditolak. 
3. Secara parsial variabel ROA berpengaruh signifikan positif terhadap variabel return saham sehingga hipotesis 3 diterima.

4. Secara parsial variabel EPS tidak berpengaruh signifikan terhadap variabel DPR sehingga hipotesis 4 ditolak.

5. Secara parsial variabel PER berpengaruh signifikan positif terhadap variabel return saham sehingga hipotesis 5 diterima.

6. Secara simultan variabel ITO,DER,ROA, EPS dan PER mempengaruhi variabel return saham.

\section{DAFTAR PUSTAKA}

Artatik, Sri.2007." Pengaruh Earning Pershare dan Price Earning Ratio Terhadap Return Saham Pada Perusahaan Manufaktur di Bursa Efek Jakarta". Skripsi S1, UNNES, Semarang. Avalable on line at www.google.com

Brigham, Eugene dan Houston Joel, 2001, “Manajemen Keuangan", Erlangga, Jakarta

Darmaji, Tjiptono \& Fakhrudin.2001." Pasar Modal Indonesia".Jakarta: Salemba Empat

Dharmastuti,Fara.2004." Analisis Pengaruh EPS,PER,ROI,Debt to Equity dan Net Profit Margin dalam Menetapkan Harga Pasar Saham Perdana(Studi pada Perusahaan yang Terdaftar di BEJ)". Jurnal Penelitian Balance,September, Vol 1,No 2

Hekinus manao dan Deswin Nur.2001,"Asosiasi Rasio Keuangan dengan Return Saham : Pertimbangan Ukuran Perusahaan serta Pengaruh Krisis Ekonomi di Indonesia". Simposium Akuntansi IV. Bandung, Agustus : Hal 923-938

Husnan, Suad \& Enny, Pudjiastuti. 2006," Dasar-dasar Manajemen Keuangan",Edisi Lima, Yogyakarta : UPP STIM YKPN

Imam Ghozali,2005," Aplikasi Analisis Multivariate dengan program SPSS".Semarang: badan Penerbit UNDIP.

IG.K.A.Ulupui,2006."Analisis Pengaruh Rasio Likuiditas, Leverage, Aktivitas, dan Profitabilitas Terhadap Return Saham.(Studi Pada Perusahaan Makanan dan Minuman dengan kategori Industri Barang Konsumsi Di BEJ).

JogiyantoH.M,2000, "Teori Portofolio dan Analisis Investasi”, edisi 2,Yogyakarta : BPFE UGM.

Mahmud M..Hanafi \& Abdul, Halim.2003," Analisis Laporan Keuangan",Edisi Revisi,Yogyakarta : AMP YKPN

Margareth.2008," Pengaruh Price Earning Ratio(PER) Terhadap Return Saham pada Sektor LQ 45 Periode 2003-2006",Skripsi S1,Universitas Widyatama Avalable on line at www.google.com

Nurul Anugerah, Abd Hamid Habbe dan M. Natsir Kasir. 2001," Korelasi antara Price Earnings Ratio (PER) dan Return Saham pada Perusahaan go public di Bursa Efek Jakarta". Simposium Akuntansi IV. Bandung,Agustus: Hal 113-129.

Prastowo, Dwi \& Yuliaty, Rifky.2005,"Analisis Laporan Keuangan Konsep dan plikasi",Yogyakarta : UPP AMP YKPN

Santoso, Singgih.2000,"Buku Latihan SPSS Statistik Parametik",Jakarta : Elakmedia Komputindo

Suad Husnan, 2001, “Dasar-dasar portofolio dan Analisis Sekuritas”, edisi 3, Yogyakarta : UPP AMP YKPN.

Tika Maya Pribawanti. 2007," Analisis Pengaruh Rasio Keuangan Terhadap Total Return Saham Pada Perusahaan Industri Manufaktur yang Membagikan Dividen Di Bursa Efek Jakarta", Skripsi S1,UNNES,Semarang,Avalabel on line at www.google.com

Totok, Budi Santoso \& Sigit, Triandaru.2006, " Bank dan Lembaga Keuangan",Edisi Revisi,Yogyakarta : AMP YKPN 
Volume 19 Nomor 1

Wahid,Wachyu Adi Winarto.2007, "Pengaruh Kinerja keuangan Terhadap Return Saham Perusahaan Manufaktur yan gTerdaftar Di Bursa Efek Jakarta", Skripsi S1, UNNES,Semarang, Avalable on line at www.google.com, www.idx.co.id

Widodo, Saniman. 2007, “Analisis Pengaruh Rasio Aktivitas, Rasio Profitabilitas, dan Rasio Pasar Terhadap Return Saham Syariah Dalam Kelompok Jakarta Islamic Index (JII) ", Tesis S2, UNDIP, Semarang, Avalabel on line at www.google.com

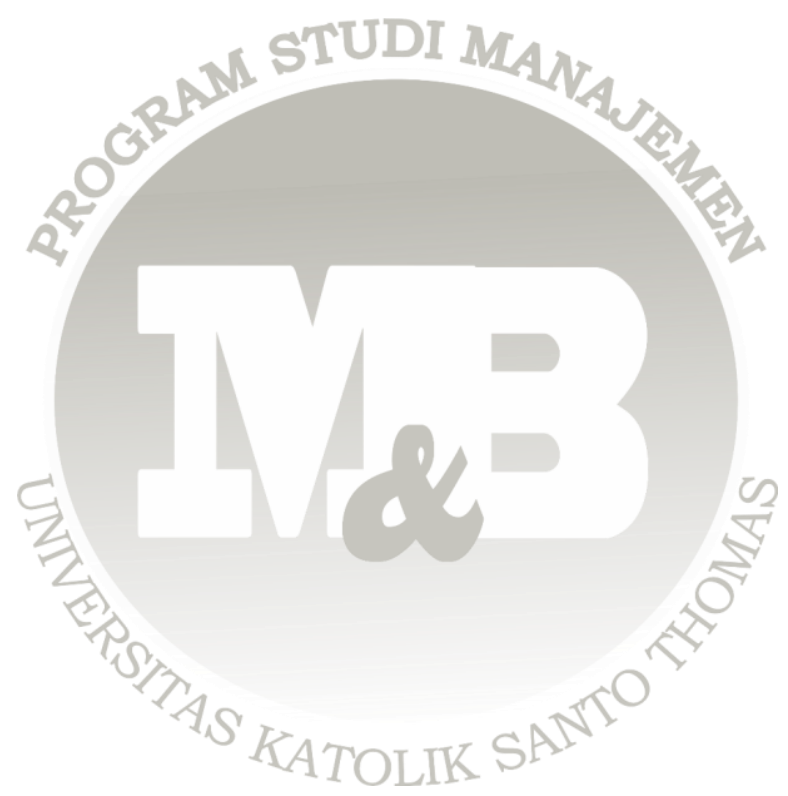

